\title{
DIE DOOD VAN DIE KIND.
}

Die dood van Totius se twee kinders in 1920 was die aanleiding tot wat as sy beste bundel beskou word, Passieblomme; maar hierdie bundel is ook op ' $n$ wel sonderlinge wyse vanaf sy eerste bundel as 't ware voorberei; vóór Passieblomme het hy reeds 'n hele aantal gedigte oor die dood van die kind geskryf. ' $n$ Hele afdeling in By die Monument (sy eerste bundel, 1908) heet Die Kind; die bekendste gedigte in hierdie groep is Daar kom hul en Kindrgraffies. Sy tweede bundel Wilgerboombogies (1912), is 'n nog merkwaardiger voorspel tot Passieblomme; dit dra die onderskrif by die titel: „Ter nagedagtenis aan drie liewe dode," Totius se vader, 'n broer en 'n suster; dit is dus nie meer onbekende liewe dodes uit die volk nie maar uit die familiekring. Die sonderlingste voorafskaduwing van Passieblomme in hierdie bundeltjie is die gedig Dit is nag, wat betrekking het op die dood van die kind. Formeel is dit 'n nog effe onbeholpe gediggie, maar reeds belangrik om Totius se opvatting daarin dat die kind só na aan die ewigheid leef dat dit deur die dood weer maklik, stil en sag daartoe kan terugkeer uit die tyd; in hierdie vroeë gedig verpersoonlik die kind vir Totius reeds 'n religieuse waarde; hy bestaan in die tyd, maar hy beleef nog die ewigheid waaruit hy kom. Omdat die mens as kind die meeste daartoe bereid is om te sterf, om m.a.w. terug te keer tot die ewigheid, daarom is sy dood in bv. oorlogstyd wreder as dié van die vrou en veral wreder as dié van die man; die kind leef immers nog so „buiten de wereld" soos Nijhoff dit in sy Kinderkruistocht noem, dat hy ook niks daarvan hoef te ly om weer daarvan te skei nie, of liewer: dit is wreed dat hy deur die toedoen van ander van die wêreld moet ly tot die dood toe; deur sy eie toedoen sal die kind hom selfs roekeloos oorgee aan die dood, soos in die pas genoemde gedig van Nijhoff. As Totius in o, die pyn-gedagte (Passieblomme) van sy gestorwe dogtertjie sê:

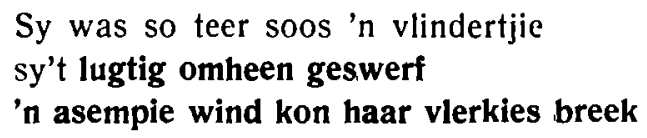

dan is dit diepsinniger beeldspraak as wat 'n mens dadelik vermoed: hy noem daarmee weer die weinige gehegtheid van die kind aan die tydelike lewe (lugtig omheen swerf) en in die laaste gesiteerde reël die sterwensbereidheid by die kind. Daarom roep die digter by die (vanuit menslike standpunt) wrede dood van die kind uit: „en-kyk watter dood moes sy/ hy sterf". Alleen al die volgorde van die afdelings: Die Kind, Die Vrou 
en Die Man in By die Monument is 'n aanduiding dat die dood van die kinders in die Tweede Vryheidsoorlog Totius die diepste aangegryp het; blykens die gedigte in hierdie bundeltjie is hy kennelik die minste geraak deur die dood van die man. En in sy derde bundel, Rachel (1913), kom daar'n paar versreëls voor waarin dit uit die sinskonstruksie baie duidelik word dat die dood van die kind in oorlogstyd vir Totius baie wreder is as dié van die vrou en verál wreder as dié van die man (die dood van die vrou word nog „vreeslik" genoem, by die dood van die man staan daar geen bywoord nie!):

as mans geryg word aan die spies

en vrouens vreeslik word geskend--

wat word dan van die kindertjies? ...

Hy sê elders in Rachel tewens dat ,die dood die ergste woed" teen die kind in oorlogstyd -en „ergste" beteken hier: „wreedste”. Agterna wil dit voorkom of Passieblomme hier al in die vermoede leef. In Gorter se Mei sê Balder dat die mens die siel nie voed nie. Hy noem dan dié mense wat die siel die suiwerste ken: alléén diè manne wat digters heet; in die vrou leef die siel suiwerder maar ook vir Gorter leef die siel die suiwerste in die kind:

Kinderen voelen haar wanneer ze na te
slapen gegaan zijn nog lang òpwaken
gedacht'loos starend voor zich ....

Totius en Gorter was digters met verskillende lewensbeskouings, en dus was hulle opvatting van die siel verskillend; hoe verskillend hulle dit ook al verstaan het, hulle was dit met mekaar digterlik eens dat die siel die suiwerste in die kind leef. Leipoldt se gedigte oor die dood van kinders in die Tweede Vryheidsoorlog het nie die religieuse implikasies wat Totius se gedigte oor die dood van die kind in bv. Rachel het nie. Vergelyk in Rachel die twee opeenvolgende gedigte: Daar lê die blokkerige stad en Kerslied; in e.g. skryf hy oor die moeder in barenswee selfs op 'n wyse wat herinner aan Middeleeuse skilderye oor die geboorte van die Christuskind:

Weldra gaan sy in moederpyn.

Dan sal-die koppe bymekaar

en in groot oë lampeskyn,-

die diere dom-verwonderd staar.

Hierdie reëls herinner tewens aan Middeleeuse gedigte oor dieselfde onderwerp: 
Die os ende oec dat eselkijn

of:

die aenbeden dat soete kindekijn

Die soet Iesus lach int hoy

Ootmoedelyc voer twee stomme beesten.

'n Ander digter van die twintigste eeu, Leopoldt, het die Middeleeuse voorstellingswyse bewus nagevolg en sê i.v.m. die drie koninge in die stal:

het licht, dat van het kind afging,

schijnt in hun groote oogen.

Enkele reëls in hierdie gedig van Totius (waarin Herodus se kindermoord uitgebeeld word as parallel van die Ëngelse se „kindermoord" in Suid-Afrika) is ook geïnspireer deur 'n gedig van Vondel oor dieselfde onderwerp: In Totius se gedig word gesê dat Herodus die kindertjies vermoor:

nes bloedjong kalfies-spene-ontruk, die tongetjies nog witgeverf van moedermelk .....

Vondel het aangaande kindertjies geskryf (in die reisang $\mathbf{O}$ Kersnacht in Gijsbrecht van Amstel):

Zij ziet de mellek op de tippen

van de bestorv' en bleke lippen, gerukt nog vers van moeder's borst.

Vondel praat van die kindertjies as „onnoz'le zielen”; ook Totius gebruik die woord "onnosel" vir die kind, soos Vondel in die betekenis van "onskuldig". Dit hoef ons nou nie te verwonder dat Totius se gedig herinner aan die voorstellingswyse in Middeleeuse gedigte oor die geboorte van Christus nie: hy bring die dood van die kind deur die vyand soos Vondel hier immers i.v.m. Herodus se kindermoord, m.a.w.: hy bring die dood van die kinders van sy volk hier i.v.m. 'n Bybelse gegewe. En nou kan ons ook begryp waarom daar nou juis in Rachel 'n Kerslied (volgende op die gedig wat ons so pas bespreek het) moet voorkom; die historiese, Afrikaanse gegewe in Rachel word deur hierdie Kerslied in 'n bo-historiese, In 'n religieuse vlak ontlaai: die Kerslied bevat 'n huldiging van die Kind van God. Totius se religieuse siening van die kind, sy opvatting van die kind as onwêrelds, het in Rachel op ' $n$ vanselfsprekende wyse gelei tot hierdie gedig oor die Kind (van God). In Rachel word tewens ook gesê:

$\mathrm{Ag}$, kindertjies is reeds vir my

'n glimlag van my God daarbo. 
En later in Passieblomme, sal Hy genoem word: „O Ewige-troue kindervrind" (As ek oor bleek-verlate sand). Vir die digter waarmee ons Totius so graag vergelyk, die Vlaming Guido Gezelle, is die hemel "'t heilig kinderland" (Gelukkige kind).

Dit sal nou, nadat ons daarop gewys het hoe die dood van die kind Totius se digterlike belangstelling gehad het reeds in By die Monument, Wilgerboombogies en Rachel, duidelik wees waarom ons aanvanklik gesê het dat Passieblomme deur die daaraan voorafgaande bundels "voorberei" is. In die intermezzo Die sterretjie in Rachel neem die digter 'n beskermende houding teenoor sy slapende kindertjies:

\author{
My kleintjies lê binne \\ in hul droompies al; \\ ek was so bang dat die ryp \\ in hul ogies sou val.
}

(Dieselfde „ryp" het die kindertjies van By die Monument om die lewe gebring). Wat die digter in hierdie versreëls in Rachel gevrees het, het die vader in 1920 as werklike gebeurtenis ervaar met die dood van sy seuntjie en dogtertjie. In oomblikke van menslikheid kon hy nie begryp waarom die van nature sterwensbereide kinders só moes sterf soos hy dit self in sy „Ter Inleiding” by Passieblomme beskryf het nie; daar is versreëls in die bundel waarin hy hulle dood „wreed" en „bitter" noem, soos 'n Vondel wat verbitterd was omdat "de felle Doot" sy dogtertjie van hom geneem het (Uitvaart van mijn dochterken); maar dieselfde Vondel kon in Kinderlijk weer sy gestorwe seuntjie laat getuig van die hemelse geluk waarin hy deelagtig is, en insgelyks is daar gedigte in Passieblomme met 'n ligte jubeling in hulle klank en ritme, soos Wanneer ons reis oor land of see, waarin ons weer daardie bekende opvatting van Totius kry oor die kind as dié vorm van menswees waarin ons kan reis „deúr ruimte en tyd, ... óór die grens van sienlikheid":

Hoe goed is dit dan om arm te wees,

'n kindjie klein en „arm van gees",

wat niks begeer en sag kan sterf

en vir die wagpos niks laat erf.

Dis dieselfde sterwensbereidheid as van die kinders in Revius se Kindermoord of in Nijhoff se Kinderkruistocht, waarin ons lees „dat ze gingen en zelfs geen afscheid namen". P. C. Boutens se Het geredde kind sê dat hy deur sy vader uit die see gered is

Juist toen het mooist begon! 
nl. die dood deur verdrinking. Eintlik skryf Totius met sy gedigte oor die dood van die kind in 'n baie sterk tradisie-nie die tradisie van 'n besondere letterkunde nie maar ' $n$ tradisie van die poësie self: die dood van die kind (nes die geboorte van die kind, in die Middeleeue van die Christuskind) en in besonder die siening van die kind as so sterwensbereid soos in Totius se poësie, is eeue oud in die letterkunde, afgesien van taal en land. F. van Eeden vertel vir ons in sy Toen ons kindje glimlachte waarom die kind so maklik afskeid kán neem van hierdie lewe:

't (is) alles hem oneigen om 't even,

want niets (verbindt) hem met dit nieuwe leeven.

Selfs by die digter van 'n ander religiese oortuiging as die Christelike, soos A. Roland Holst, kry ons dieselfde perspektief op die kind, nl. dat hy die ewige met hom meedra binne die tydruimtelike wêreld en dat hy ligtelik, en graag selfs, van lg. afskeid neem. Die enigste menslike gestalte wat Holst hom "voorbij den tijd" kan voorstel, is die kind (Het gestorven kind); die kind kom "vlakbij uit het eeuwige leven" (Van een kind I). In Totius se gedigte oor die dood van die kind hoor ons die Bybelse gedagte, soms byna woordeliks soos in die laaste sitaat uit sy poësie hierbo (beginnende met „Hoe goed is dit dan om arm te wees”); vgl. daardie sitaat o.a. met Matthéüs 18: 3: „Voorwaar Ek sê vir julle, as julle nie verander en soos die kindertjies word nie, sal julle nooit in die koninkryk van die hemele ingaan nie".

Ons het hierbo gepraat van die tradisic van die poësie self.-Taamlik algemeen in die poësie word die kind in sy slaap voorgestel (vgl. reeds Totius se Die sterretjie hierbo), omdat die slaap die suiwer sielstoestand, die kontak met die ewige beter simboliseer as die wakende toestand waarin die sintuie oop staan vir die tydelike verskyningsvorme, en omdat die slaap die voorafskaduwing van die dood is en vir die Christus dus die voorafskaduwing van die ewige lewe (John Donne, Divine Poems), Dit is selfs algemene, tradisionele beeldspraak om te praat van "ontwaking" uit dia dood, soos in F. van Eeden se Paulus Ontwaken: „Hij is nie ingeslapen maar in 't Licht ontwaakt", of soos in Van Eyck se Ik zal nog waarin hy praat van die "laatst ontwaken ... in 't andre land"; John Donne sê "One short sleep past, wee wake eternally." Of dink maar aan D. F. Malherbe se bekende sonnet oor die slapende kind; die vader van daardie slapende kind in sy arms bid:

Sluit so my oë, God, wanneer vir my $\mathrm{U}$ Engel wenk ter laaste, lange rus. 
Ook Gorter (vgl. hierbo) stel die kind in sy sielservaring voor by slapenstyd en Holst sê in" Het kindji:

\author{
Waar het kindje slaapt \\ is het àl weer goed: \\ samen toegedekt \\ liggen ziel en bloed; \\ alle duistere daden in het huis bedreven \\ vonden in een wiegelied vergeven.
}

Dink voorts aan die talryke wiegeliedere wat ons ken; die baie anoniemes, die onpretensieuse wiegelied van bekende digters soos Gezelle se Slaapt, die diepsinniger en gestileerde wiegelied soos Leopold se Laat de luiken geloken zljn, of selfs die diep simboliese wiegelied soos William Blake se A cradle song. In laasgenoemde gedig is die kind weer religieuse simbool; dit is verwant aan bv. Holst se

$$
\begin{aligned}
& O \text {, het lachen van het kind } \\
& \text { voor de wereld en na haar einde- } \\
& \text { van een kleine blinkende wind } \\
& \text { vertelt het, die eens uitgezonden } \\
& \text { zal worden over trots en pijn, } \\
& \text { totdat Babylon en Londen } \\
& \text { vergeven en vergeten zijn. }
\end{aligned}
$$

Maar Blake se Cradle song is in sy Christelike simboliek veral weer verwant aan die poësie van Totius-ons hoor selfs Totius se reeds gesiteerde verse „Ag, kindertjies is reeds vir my/ 'n glimlag van my God daarbo" daarin:

Sweet babe, in thy face

Holy image I can trace.

Sweet babe, once like thee,

Thy maker lay and wept for me.

Wept for me, for thee, for all,

When he was an infant small

Thou his image ever see,

Heavenly face that smiles on thee,

Smiles on thee, on me, on all;

Who became an infant small.

Infant smiles are his own smiles;

Heaven and earth to peace beguiles.

Ook in Totius se poësie benader die mens, sélfs die volwassene, die ewigheidstoestand d.m.v. die slaap. In Trekkerswee (afd. 1, vii) word daar 
vertel hoe die mens tot homself inkeer in sy slaap en "dan worstel daar by halwe lig/ die hart"; die slaap word voorgestel $(2, v)$ as die tyd wanneer „die siel ... wakker word (om) te peins aan God";

Sy doet gelyk die voël by nag,

wat die vlerk nie vliegend meer wil strek, maar die koppie in die dons gaan dek-

so peins die siele aan God.

Nou hou die slaap en kindwees vir Totius só 'n noue verband dat dit in sy gedigte selfs voorkom dat die volwassene deur die slaap die kinderlike staat benader en sodoende dan die leefwyse op die grens van die tyd sóseer benader die volwassene vir hom deur middel van die slaap die kinderlike, daardie toestand van onttrek wees aan die tydruimtelike sfeer, dat die kritiese mens dit nouliks sal kan begryp en meemaak; ek verwys slegs na As die dag my klaar gekwel het en Nou is die dag verby, albei in Skemering. (Reeds in Rachel is daar sprake van 'n „wense na kindsheid".) Ook die afgeleefde mens wat teen "die skemerberge" van die dood stuit, word by hierdie oordragtelik bedoelde slapenstyd weer „soos 'n kind wat skaars kan loop" (Gebed in Skemering). W. Blake ver-beeld die siklus van die menselewe in The ecchoing green (Songs of Innocence); hy noem die kind, die middeljarige, die afgeleefde; ook hy stel lg. voor met die kind, die kind wat ook vir hom, soos vir Totius, religieuse simbool is en die metafisiese duidelik in hom omdra.

Dit plaas ons alleen voor die begryplike raadsplan van God dat Totius, by wie die digterlike belangstelling in die dood van die kind reeds vanaf sy eerste bundel so opmerklik was en vir wie die kind so 'n duidelike religieuse waarde gehad het, later twee eie kinders deur die dood moes verloor om daarná sy beste gedigte te skryf.

T. T. CLOETE. 